\title{
Assessment of Heavy Metals Uptake and Translocation by Aquilaria malaccensis Planted in Soils Containing Sewage Sludge
}

\author{
${ }^{1}$ Keeren Sundara Rajoo, ${ }^{1,3}$ Arifin Abdu, ${ }^{1,3}$ Hazandy Abdul-Hamid, \\ ${ }^{2}$ Daljit Singh Karam, ${ }^{2}$ Shamshuddin Jusop, ${ }^{1}$ Aiza-Shaliha Jamaluddin and ${ }^{1}$ Wong Wan Zhen \\ ${ }^{1}$ Department of Forest Management, Faculty of Forestry, \\ ${ }^{2}$ Department of Land Management, Faculty of Agriculture, \\ ${ }^{3}$ Institute of Tropical Forestry and Forest Products, \\ Universiti Putra Malaysia, 43400 UPM Serdang, Selangor, Malaysia
}

Received 2013-04-13, Revised 2013-07-03; Accepted 2013-07-25

\begin{abstract}
Increase in human population has resulted in an enormous growth in the volume of wastewater. The conventional methods of sewage sludge disposal, that is the by-product of wastewater treatment, are costly and not environment-friendly. An ideal way for sewage sludge management is by using it as a soil amendment in agricultural land due to sewage sludge's high organic matter content. However, sewage sludge contains high levels of heavy metals that can be harmful to both plants and the environment. Hence, these metals need to be removed before the sewage sludge is to be used as a soil amendment. The objective of this study was to assess the potential of Aquilaria malaccensis to uptake and translocate heavy metals found in sewage sludge. A.malaccensis seedlings were planted on six different planting media: T0/Control (100\% soil), T1 (80\% soil and 20\% sewage sludge), T2 (60\% soil and 40\% sewage sludge), T3 (40\% soil and $60 \%$ sewage sludge), T4 (20\% soil and 80\% sewage sludge) and T5 (100\% sewage sludge) for the duration of 16 weeks. The growth performance of height and basal diameter was measured using diameter tape and venier caliper every two weeks, respectively. The average dry weight biomass of A.malaccensis was measured using destructive sampling at 16 weeks after planting. Plant samples were collected after harvest and soil samples were collected before planting and after harvesting. Atomic Absorbtion Spectrophotometer (AAS) was used to determine the concentration of heavy metals in the planting media and the plant parts (leaves, stem and roots). The highest growth of A.malaccensis was recorded for the T5 growth media. The highest concentration of Fe in the roots of the A.malaccensis plant was in the T5 growth media $(2770.75 \mathrm{ppm})$. The highest accumulation of $\mathrm{Zn}(95.62 \mathrm{ppm})$ was recorded in the roots of A.malaccensis in the T5 growth media, whereas the stem of the A.malaccensis in $\mathrm{T} 5$ recorded the highest $\mathrm{Cd}$ accumulation $(3.75 \mathrm{ppm})$. The highest $\mathrm{Pb}$ uptake was recorded in the roots of A.malaccensis in T5 (39.79 ppm), while the lowest accumulation of $\mathrm{Pb}$ was noted in the leaves of the A.malaccensis in control (16.08 ppm). The highest Translocation Factor (TF) (2.00) for Cd was recorded in T5. The lowest Bioconcentration Factor (BCF) for $\mathrm{Cu}$ was recorded at $\mathrm{T} 5(0.18)$. The highest $\mathrm{TF}$ for $\mathrm{Pb}$ was recorded in control (1.50), while the lowest was in T5 (1.23). The BCF for Zn was lowest in T5 (0.64). The A.malaccensis plant was found to be suitable for taking up heavy metals from sewage sludge especially $\mathrm{Cd}$ and $\mathrm{Cu}$. The roots of A.malaccensis are ideal in uptaking and storing Fe, while the stem of the A.malaccensis plant is ideal for the uptake and accumulation of $\mathrm{Cd}$. More studies need to be conducted, especially in field conditions, to optimize the potential of the A.malaccensis plant as a phytoremediator.
\end{abstract}

Keywords: Aquilaria Malaccensis, Phytoremediation, Heavy Metals, Sewage Sludge, Translocation Factor (TF), Bioconcentration Factor (BCF)

Corresponding Author: Arifin Abdu, Department of Forest Management, Faculty of Forestry, Universiti Putra Malaysia, 43400 UPM Serdang, Selangor, Malaysia 


\section{INTRODUCTION}

There has been an increased awareness to the importance of green technology to mitigate harms to the environment (Olivier, 2006). This environmental awareness was largely fueled during the 1990's, where climate change issues are becoming more prevalent concerns of the world (Miranda, 2012). Ever since then, there has been increasing evidences leading to believe that human activities are primary causes of environmental damage including climate change (Miranda, 2012). Climate change occurs naturally; however, various human activities have led to climate change happening at an alarming and potentially hazardous pace (Nicholas and Daniel, 2008). These anthropogenic activities include the burning of fossil fuels, the use of chemicals such as inorganic fertilizers, deforestation and waste disposal (Miranda, 2012). In order to combat climate change and potential harms to the environment, green technology is continuously being developed in order to preserve the quality of human life while preserving the environment (Olivier, 2006). One such activity that is currently the focus of green technology development is the disposal of sewage sludge.

Rapid industrialization and urbanization due to the ever increasing human population, has caused the volume of wastewater to increase exponentially (Abdu et al., 2011). When wastewaters are treated at wastewater treatment facilities, it produces solid waste products known as sewage sludge (Abdu et al., 2011). Malaysia is currently estimated to produce about 5 million cubic meters of sewage sludge per year and the amount has been estimated to reach 7 million cubic meters per year by 2022 (IWK, 1997). Due to the increasing amount of sewage sludge produced is constantly increasing; the disposal of sewage sludge is increasingly becoming a major distress not only to Malaysia, but globally as well (Ghafoori et al., 2011). Sewage sludge disposal has also been linked to climate change, since conventional methods of disposing such as burning produces methane. Besides that, other methods of disposal, either by land or sea, has also raised numerous environmental concerns (Abdu et al., 2011).

The conventional environment-friendly methods of sewage sludge disposal are very costly, time consuming and requires expertise knowledge (Majid et al., 2011). A cost effective and environment-friendly method for sewage sludge management is by using it as a soil amendment in agricultural land (Abdu et al., 2011).
Sewage sludge has high organic matter content, making it suitable to be used as an organic fertilizer (Singh and Argawal, 2008). Hence, the application of sewage sludge will also reduce the dependency and the need for inorganic fertilizers, making it a very credible environment-friendly option (Majid et al., 2011). However, sewage sludge contains high amounts of heavy metals, especially due to industrial wastewater contamination (Raymond and Felix, 2011). Previous studies have also indicated that sewage sludges in Malaysia have very high heavy metal content (IWK, 1997). Therefore, land disposal for extensive periods would result in the accumulation of toxic levels of heavy metal due to heavy metals being non-degradable and dangerous pollutants (Raymond and Felix, 2011).

Heavy metals occur naturally in soil but in non-toxic levels and some of these heavy metals are needed in small amounts by plants and animals (Rascio and Navari-Izzo, 2011). However, heavy metals are not readily metabolized and accumulate in the soft tissues, making it toxic when in high concentrations (Rascio and Navari-Izzo, 2011). Heavy metal, that is chemical elements with a specific gravity that is at least five times the specific gravity of water (Kvesitadze et al., 2006), have been characterized by the United States Environmental Protection Agency (USEPA) and state regulation as trace elements that can be harmful to the environment, human, animals and plants. Hence, sewage sludge has the potential to be beneficial to plants due to its high nutrient content; however, indiscriminate usage of sewage sludge as a soil amendment would result in detrimental effects to the plants because of the presence of high amounts of heavy metal, such as $\mathrm{Cd}, \mathrm{Zn}, \mathrm{Fe}$ and $\mathrm{Cu}$ (Raymond and Felix, 2011).

There are numerous methods of managing soil contamination such as heavy metals; one such organic method is known as phytoremediation (Majid et al., 2011). Phytoremediation is a technology that employs plants to degrade, remove or remediate contaminants from soil (Karen et al., 2009). Phytoremediation does not damage soil structure (Purakayastha and Chhonkar, 2010) and is an enviroment-friendly method of removing soil contamination. Plants that are suitable for phytoremediation should have certain selected plants characteristic that is it should be fast growing, has high biomass and a natural tolerance to toxic substances such as heavy metals and salinity (Majid et al., 2011). The detoxification potential of the plant is determined by the rate and depth of 
contaminant uptake from the soil, accumulation in the plant cell and the degree of contaminant transformation to regular cell metabolites (Jos et al., 2009).

Plants that are able to accumulate metals without exhibiting signs of toxicity make excellent phytoremediators (Bennett et al., 2003). At least 45 plant families and individual species have been identified as hyper metal accumulating plant species, that is have the capability to accumulate different metals (Purakayastha and Chhonkar, 2010). Some of these plant families are Brassicaceae, Fabaceae, Euphorbiaceae, Asteraceae, Lamiaceae and Scrophulariaceae.

For this study, the plant species A.malaccensis was selected to determine its potential to clean up toxic heavy metals from sewage sludge. Aquilaria malaccensis, (Family: Thymelaeaceae) is commonly known as "karas" is locally found in Indonesia and Malaysia. A.malaccensis are widely harvested from the wild due to a highly valuable and commercial resinous wood used as incense Reeves and Baker (2000). This species have been studied extensively on its taxonomy and morphology (Soehartono and Newton, 2000). Studies have also been conducted on A. malaccensis reproductive ecology (Soehartono and Newton, 2000). However, there is still a lack of research on the potential of A.malaccensis to be used as a phytoremediator species. Hence, the objective of this study was to evaluate the ability of A.malaccensis to uptake and translocate the heavy metals from sewage sludge contaminated soil.

\section{MATERIALS AND METHODS}

\subsection{Site Description and Planting Materials}

The study was conducted at the greenhouse of University Agriculture Park, Universiti Putra Malaysia $\left(4^{\circ} 062 \mathrm{~N}\right.$ latitude and $101^{\circ} 162 \mathrm{E}$ longitude) for 16 weeks (January 2012 to April 2012). Relative humidity in the greenhouse was $65 \%$, while the temperature at greenhouse was $27^{\circ} \mathrm{C}$ in the morning and $35^{\circ} \mathrm{C}$ in the evening. The seedlings of the A.malaccensis tree were germinated from cuttings of the mature stem and planted in polybags $(16.0 \times 16.0 \mathrm{~cm})$ in the Faculty of Forestry nursery. The growing medium for the A.malaccensis seedlings were in the proportions of soil: organic matter: river sand in a $3: 2: 1$ ratio. The seedlings were transplanted into suitable plastic pots $(32.0 \mathrm{~cm}$ height, $106.0 \mathrm{~cm}$ upper diameter and 69.0 lower diameter) that were filled up with the mixture of soil and sewage sludge after one month.

\subsection{Plant and Soil Sampling}

There were six different levels of treatments used in this study, with four replicates for each treatment. The treatment consisted of a mixture of soil and dry sewage sludge and the control consisted of only soil: T0/Control (100\% soil), T1 (80 soil and 20\% sewage sludge), T2 (60 soil and 40\% sewage sludge), T3 (40 soil and 60\% sewage sludge), T4 (20 soil and 80\% sewage sludge) and T5 (100 sewage sludge). The pots were labelled according to their compositions. The Completely Randomized Design (CRD) was used in this study. Soil samples were collected from each pot before planting and after harvesting. They were then kept in standard plastic containers and air-dried before physico-chemical analyses.

\subsection{Soil Analysis}

Soil $\mathrm{pH}$ was determined by glass-electrode at 1:5 soil to solution ratio after reciprocal shaking for $1 \mathrm{~h}$ (Jackson, 1973). Soil samples were collected from each pot before planting and after harvesting, kept in standard plastic containers and air-dried prior chemical analyses. AAS was used for analyzing the concentrations of selected heavy metals [iron $(\mathrm{Fe})$, zinc $(\mathrm{Zn})$, cadmium $(\mathrm{Cd})$, lead $(\mathrm{Pb})$ and copper $(\mathrm{Cu})]$ in the planting media and plant parts and aqua regia was used as the extractant (Sahoo et al., 2009). Total carbon was determined using loss on ignition method.

\subsection{Plant Growth and Biomass Measurement}

The heights, diameters and number of leaves of the A.malaccensis plants were measured every two weeks throughout the study period with diameter tape, while the basal diameter was measured using a venier caliper every two weeks. Plant biomass was measured separately according to leaves, stems and roots. The loss in weight upon drying is the weight originally present. The moisture content of the sample was calculated using Equation 1:

$\% \mathrm{~W}=\frac{\mathrm{A}-\mathrm{B}}{\mathrm{B}} \times 100$

where, $\% \mathrm{~W}=$ percentage of moisture in the sample, $\mathrm{A}=$ weight of wet sample and B = weight of dry sample.

Translocation Factor (TF) and Bioconcentration Factor (BCF). The plant's ability to accumulate metals from soils and translocate metals from roots to shoots was estimated using the translocation factor (Equation 2) and the concentration in roots to soil was estimated using bioconcentration factor (Equation 3). 


$$
\begin{aligned}
& \mathrm{TF}=\frac{\text { Metal concentration aerial parts }}{\text { Metal concentration in roots }} \\
& \mathrm{BCF}=\frac{\text { Metal concentration in roots }}{\text { Metal concentration in soil }}
\end{aligned}
$$

\subsection{Statistical Analysis}

The analyses for growth and heavy metals in the soil, sludge and plant parts were done following the Analyses of Variance (ANOVA) technique and the mean values were adjusted using Tukey's as a post hoc test $(\mathrm{p} \leq 0.05)$. A comparison using the Student's $\mathrm{t}$ test at a $5 \%$ level was done to detect any significant differences between samples taken before planting and after harvesting. All data were statistically analyzed using the statistical package for SPSS 16.0 program.

\section{RESULTS}

\subsection{General Properties of the Growth Media}

The soil texture was found to be silty clay. All treatments initially had low $\mathrm{pH}(4.39$ to 5.56) and it increased at harvest (4.50 to 5.61) (Table 1). T3 recorded the highest change in soil $\mathrm{pH}$ (5.13 to 5.32).
Total carbon of the growth media had a direct correlation with the percentage of sewage sludge in the treatment level; the higher the percentage of sludge in the growth media, the higher was the total carbon of the growth media (Table 1). Before planting, the highest total carbon was recorded in T5 $(13.33 \%)$ and the lowest was in the T0 $(0.71 \%)$. After harvest, total carbon decreased in all the treatments, except in T0. The maximum total carbon content $(6.58 \%)$ was found in $\mathrm{T} 5$, while the minimum content was recorded in the T0 $(1.05 \%)$.

\subsection{Growth Performance and Plant Biomass}

The results in Table 2 showed significant differences $(p \leq 0.05)$ among the treatments in terms of total height and basal diameter. A.malaccensis planted in the T5 recorded the highest total height $(47.55 \mathrm{~cm})$, which was closely followed by the T4 $(46.83 \mathrm{~cm})$. The basal diameter showed similar pattern with total height. After week 8, basal diameter was constant for all treatments except for T1 and T2 which increased slightly. Treatment $5(6.73 \mathrm{~cm})$ showed the highest total basal diameter. After 16 weeks, treatment 5 produced the highest number of leaves (20). As shown in Fig. 1c, the lowest number of leaves was recorded by T0 (17). Overall, the numbers of leaves for all treatment levels were almost similar.

\begin{tabular}{|c|c|c|c|c|}
\hline \multirow[b]{2}{*}{ Treatment } & \multicolumn{2}{|l|}{$\mathrm{pH}$} & \multicolumn{2}{|l|}{ Total-C } \\
\hline & B & A & $\mathrm{B}$ & A \\
\hline T0 & $4.39 \pm 0.04 \mathrm{a}$ & $4.50 \pm 0.16 \mathrm{a}$ & $0.71 \pm 0.07 \mathrm{a}$ & $1.05 \pm 0.11 \mathrm{a}$ \\
\hline $\mathrm{T} 1$ & $4.78 \pm 0.16 \mathrm{a}$ & $4.85 \pm 0.14 \mathrm{a}$ & $1.70 \pm 0.55 \mathrm{a}$ & $1.64 \pm 0.68 \mathrm{a}$ \\
\hline $\mathrm{T} 2$ & $4.92 \pm 0.05 \mathrm{a}$ & $5.10 \pm 0.09 a$ & $4.02 \pm 0.68 \mathrm{a}$ & $2.63 \pm 0.16 b$ \\
\hline $\mathrm{T} 3$ & $5.13 \pm 0.37 \mathrm{a}$ & $5.32 \pm 012 \mathrm{a}$ & $6.15 \pm 0.26 \mathrm{a}$ & $3.00 \pm 1.08 \mathrm{~b}$ \\
\hline $\mathrm{T} 4$ & $5.39 \pm 0.56 \mathrm{a}$ & $5.48 \pm 0.45 \mathrm{a}$ & $8.65 \pm 0.44 \mathrm{a}$ & $4.53 \pm 1.13 b$ \\
\hline $\mathrm{T} 5$ & $5.56 \pm 0.26 \mathrm{a}$ & $5.61 \pm 0.26$ & $13.33 \pm 1.32 \mathrm{a}$ & $6.58 \pm 1.50 \mathrm{~b}$ \\
\hline
\end{tabular}

Table 1. The $\mathrm{pH}$ and total-C (\%) content in growth media by different levels of sewage sludge

Note: Different letter within a column indicate significant differences between means following tukey's test (P $\leq 0.05)$; T0-control (100\% soil), T1 (80\% soil and 20\% sewage sludge), T2 (60\% soil and 40\% sewage sludge), T3 (40\% soil sewage sludge), T4 (20\% soil and 80\% sewage sludge) and T5 (100\% sewage sludge); B (before planting), A (after harvesting)

Table 2. Total height, basal diameter and number of leaves for $A$. malaccensis at 16 weeks after planting

\begin{tabular}{llll}
\hline Treatment & Height $(\mathrm{cm})$ & Basal diameter $(\mathrm{mm})$ & No. leaves \\
\hline T0 & $41.77 \mathrm{a}$ & $5.46 \mathrm{a}$ & $16 \mathrm{a}$ \\
T1 & $43.60 \mathrm{a}$ & $5.80 \mathrm{a}$ & $17 \mathrm{a}$ \\
T2 & $44.23 \mathrm{a}$ & $6.04 \mathrm{a}$ & $19 \mathrm{a}$ \\
T3 & $45.69 \mathrm{ab}$ & $6.47 \mathrm{ab}$ & $17 \mathrm{a}$ \\
T4 & $86.83 \mathrm{~b}$ & $6.53 \mathrm{~b}$ & $18 \mathrm{a}$ \\
T5 & $47.55 \mathrm{~b}$ & $6.73 \mathrm{~b}$ & $20 \mathrm{a}$ \\
\hline
\end{tabular}

Note: Different letter within a column indicate significant differences between means following tukey's test (P $\leq 0.05)$; T0 control (100\% soil), T1 (80\% soil and 20\% sewage sludge), T2 (60\% soil and 40\% sewage sludge), T3 (40\% soil and $60 \%$ sewage sludge), T4 (20\% soil and $80 \%$ sewage sludge) and T5 (100\% sewage sludge) 
Keeren Sundara Rajoo et al. / American Journal of Applied Sciences 10 (9): 952-964, 2013
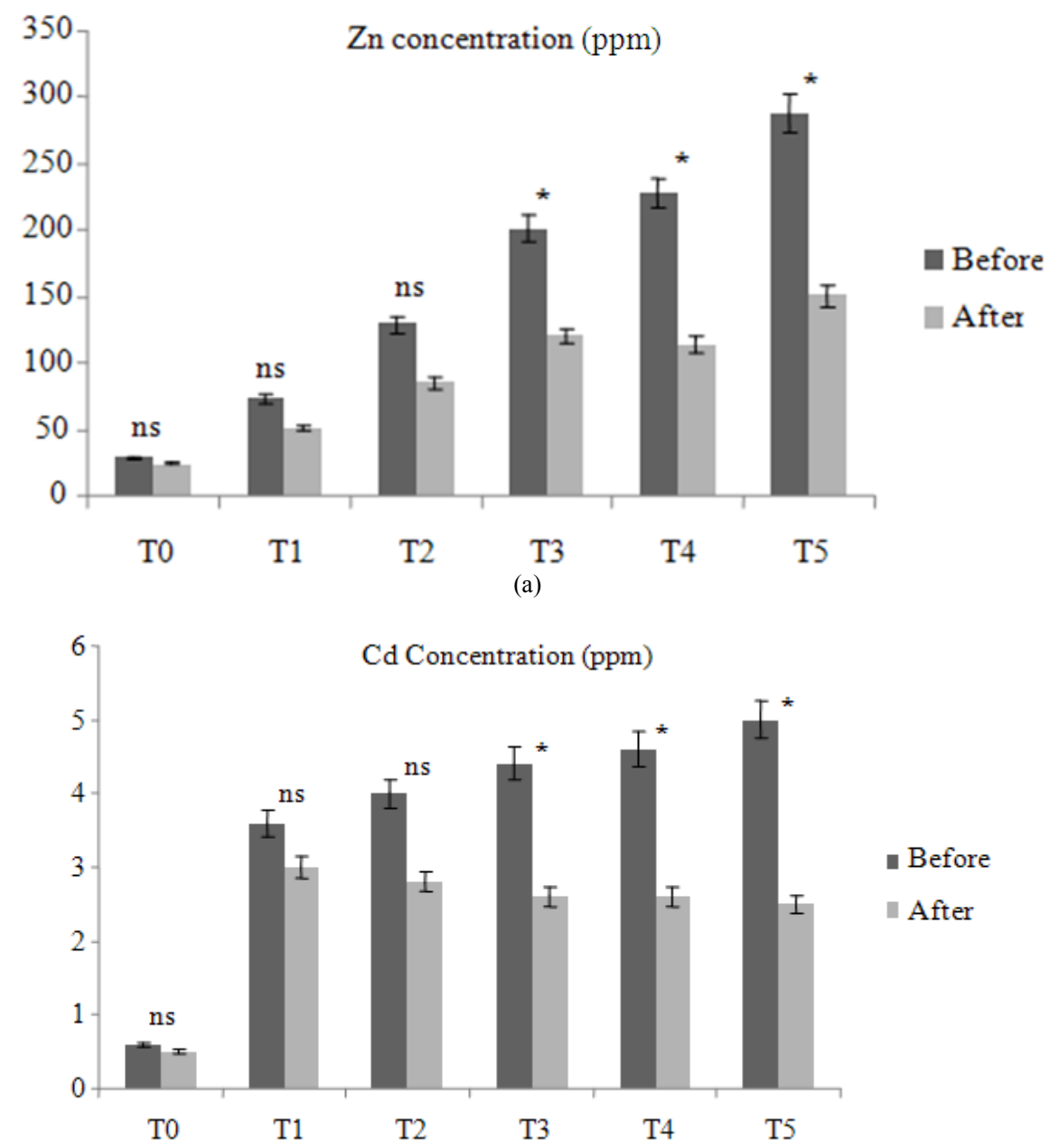

(b)

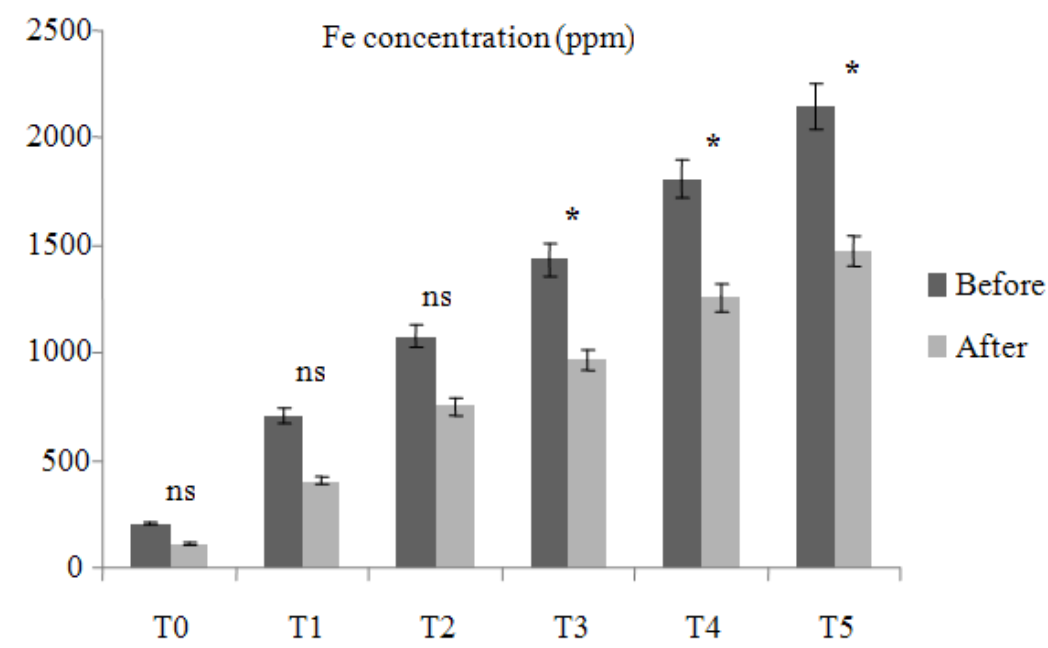

(c) 

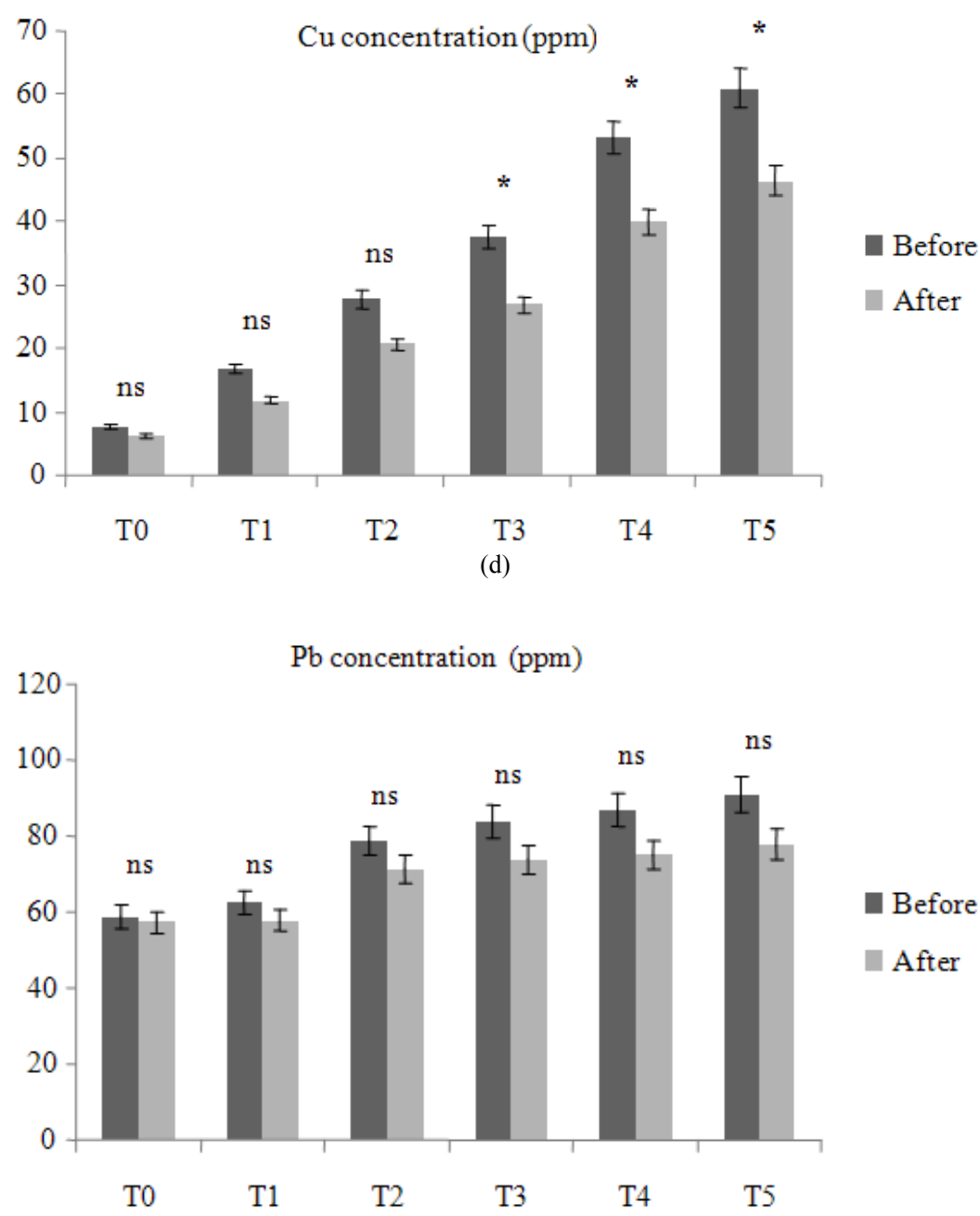

(e)

Fig. 1. The concentrations of $\mathrm{Zn}(\mathrm{a}), \mathrm{Cd}(\mathrm{b}), \mathrm{Fe}(\mathrm{c}), \mathrm{Cu}(\mathrm{d})$ and $\mathrm{Pb}(\mathrm{e})$ in growth medium before planting and after harvesting. * indicate significant difference between means at each treatment before planting and after harvesting according to a Student's t-test ( $\mathrm{p} \leq 0.05)$, ns indicates no significant difference. T0, (100\% soil-control), T1, ( $80 \%$ soil and $20 \%$ sewage sludge), T2, (60\% soil and $40 \%$ sewage sludge), T3, (40\% soil and 60\% sewage sludge), T4, (20\% soil and $80 \%$ sewage sludge), T5, (100\% sewage sludge)

Table 3. Average dry weight biomass for leaves, stem and roots of A. malaccensis at 16 weeks after planting

\begin{tabular}{llll}
\hline Treatment & Roots & Stem & Leaves \\
\hline T0 & $71.88 \mathrm{a}$ & $63.65 \mathrm{a}$ & $61.52 \mathrm{a}$ \\
T1 & $72.19 \mathrm{a}$ & $64.76 \mathrm{a}$ & $64.17 \mathrm{a}$ \\
T2 & $73.17 \mathrm{a}$ & $65.94 \mathrm{a}$ & $65.63 \mathrm{a}$ \\
T3 & $74.38 \mathrm{a}$ & $67.66 \mathrm{a}$ & $67.21 \mathrm{a}$ \\
T4 & $75.06 \mathrm{a}$ & $67.83 \mathrm{a}$ & $68.42 \mathrm{a}$ \\
T5 & $75.18 \mathrm{a}$ & $70.00 \mathrm{a}$ & $68.73 \mathrm{a}$ \\
\hline
\end{tabular}

Note: Different letter within a column indicate significant differences between means following tukey's test ( $\mathrm{p} \leq 0.05$ ); T0 control (100\% soil), T1 (80\% soil and 20\% sewage sludge), T2 (60\% soil and 40\% sewage sludge), T3 (40\% soil and $60 \%$ sewage sludge), T4 (20\% soil and $80 \%$ sewage sludge) and T5 (100\% sewage sludge) 
Keeren Sundara Rajoo et al. / American Journal of Applied Sciences 10 (9): 952-964, 2013

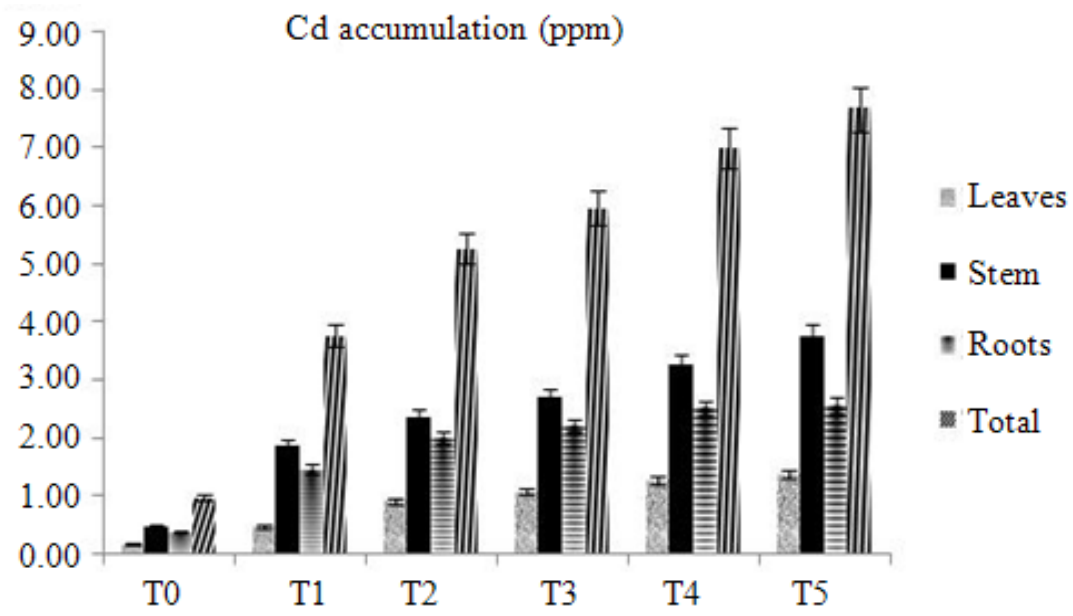

(a)
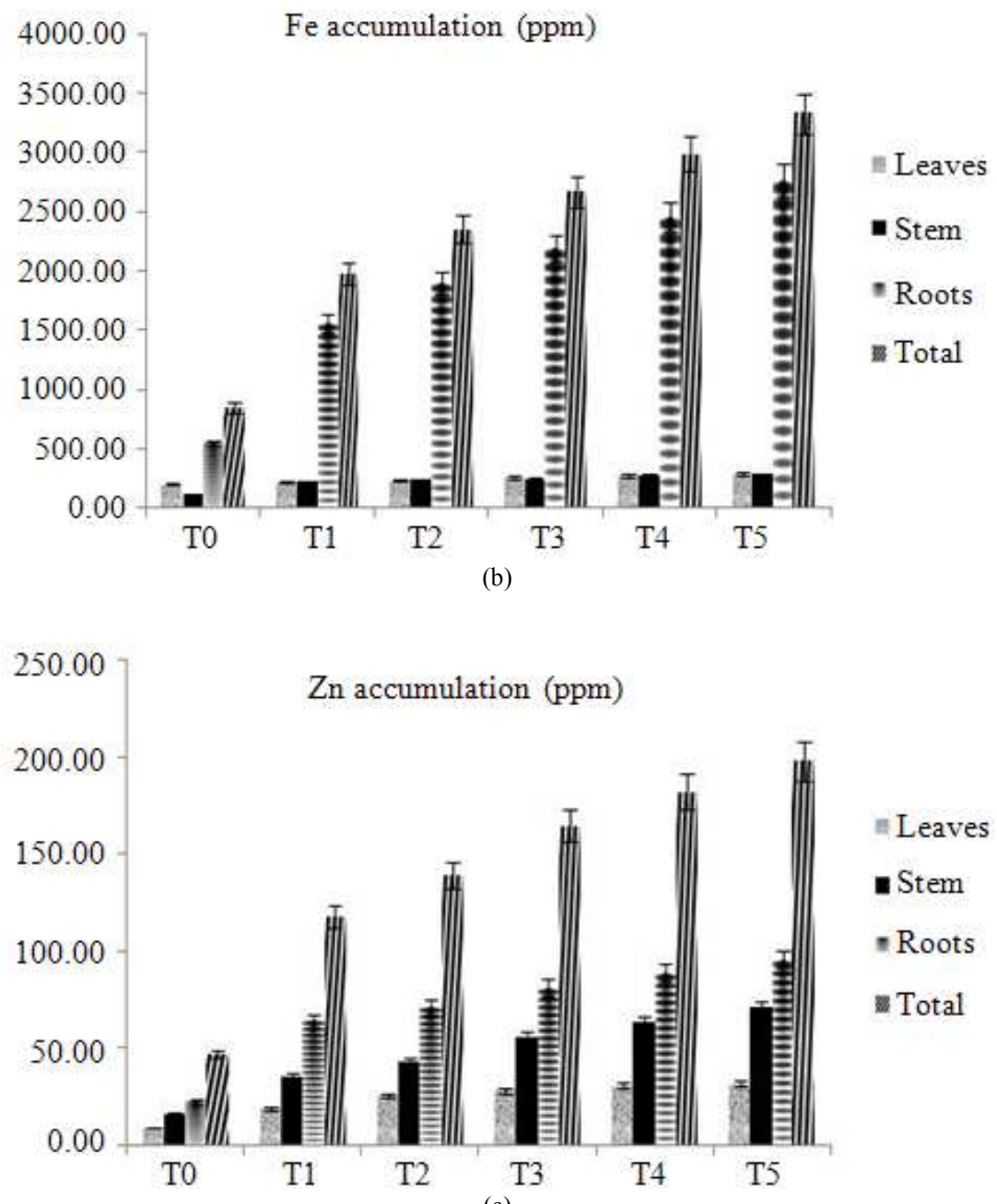

(c) 


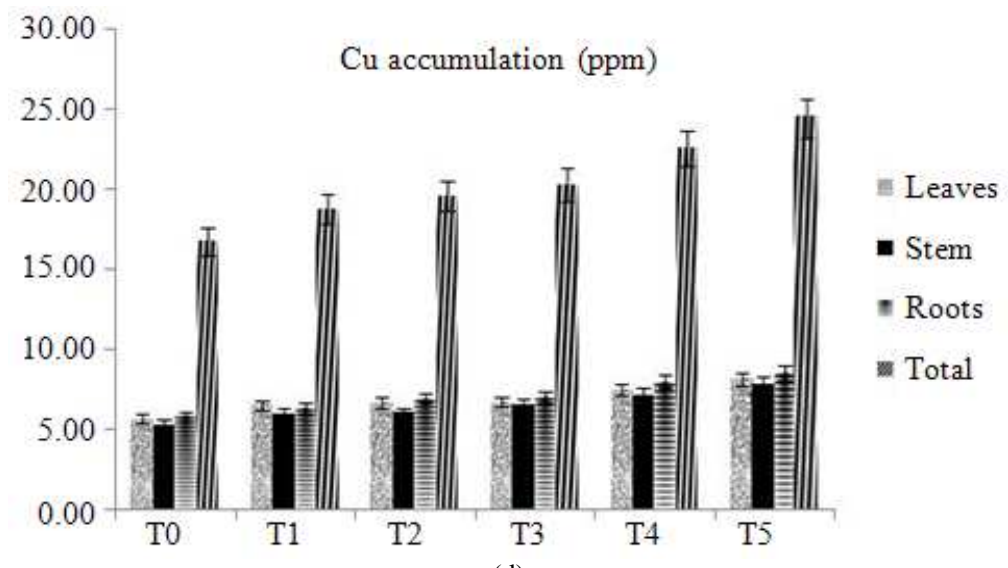

(d)

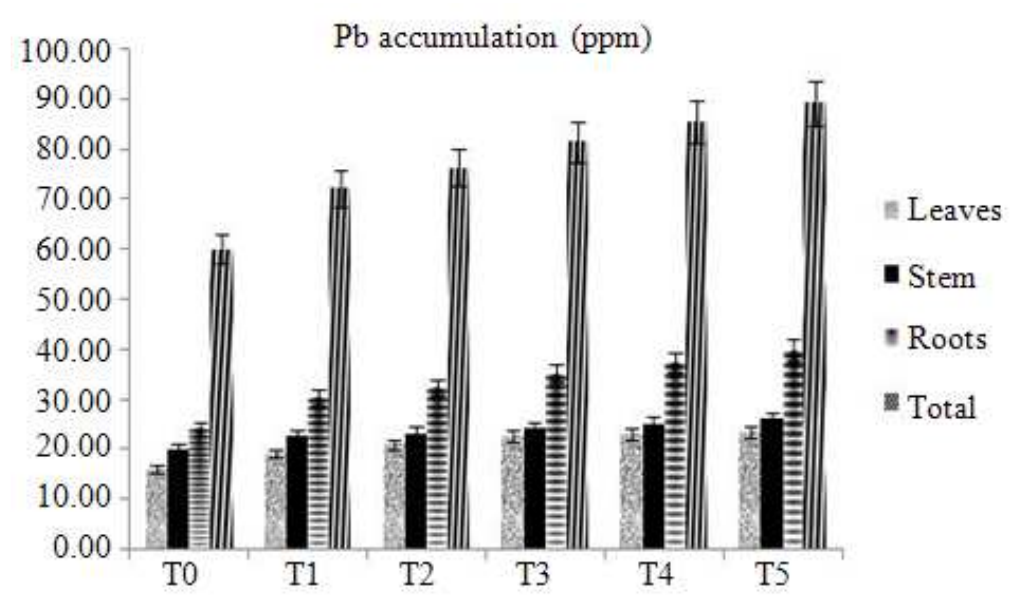

(e)

Fig. 2. Accumulation of $\mathrm{Cd}(\mathrm{a}), \mathrm{Fe}(\mathrm{b}), \mathrm{Zn}(\mathrm{c}) \mathrm{Cu}(\mathrm{d})$ and $\mathrm{Pb}(\mathrm{e})$ concentrations in the plant parts after harvesting of A.malaccensis plant as influenced by different treatments. T0 $=100 \%$ soil, $\mathrm{T} 1=80 \%$ soil $+20 \%$ sewage sludge, $\mathrm{T} 2=60 \%$ soil $+40 \%$ sewage sludge, $\mathrm{T} 3=40 \%$ soil $+60 \%$ sewage sludge, $\mathrm{T} 4=20 \%$ soil $+80 \%$ sewage sludge, $\mathrm{T} 5=100 \%$ sewage sludge

The results in Table 3 showed not significantly different $(\mathrm{p} \leq 0.05)$ in the plant biomass between the treatments for all plant parts. T5 produced the highest biomass for roots (75.18), stem (70.00) and leaves (68.73), respectively. T0 produced the lowest biomass for roots (71.89), stem (63.65) and leaves (61.52), respectively.

\subsection{Heavy Metal Concentrations in Growth Medium Before Planting and After Harvesting}

A.malaccensis was found to be able to remove high concentrations of heavy metals from the sewage sludge $(\mathrm{Zn}, \mathrm{Pb}, \mathrm{Fe}, \mathrm{Cd}$ and $\mathrm{Cu}$ ), especially in $\mathrm{T} 5$ where the planting media contained $100 \%$ sewage sludge. The $\mathrm{Zn}$ content of the sewage sludge was $287.44 \mathrm{ppm}$ before planting in $\mathrm{T} 5$ and after harvesting, the $\mathrm{Zn}$ level decreased to 150.48 ppm (Fig. 1a).The highest decrease in Cd levels in the A.malaccensis growth media was observed in T5, where the level of Cd decreased by 2.5 ppm (Fig. 1b). The level of Fe in the T5 growth media decreased after harvesting (1473.8 ppm) compared to the initial Fe level of $2144.6 \mathrm{ppm}$ (Fig. 1c). The highest decrease in $\mathrm{Cu}$ level in the A.malaccensis growth media was observed in $\mathrm{T} 5$, where the level of $\mathrm{Cu}$ decreased by 14.57 ppm (Fig. 1d). The level of $\mathrm{Pb}$ in the $\mathrm{T} 5$ growth media decreased after harvesting (77.80 ppm) compared to the initial $\mathrm{Pb}$ level (90.79 ppm), as shown in Fig. 1e.

\subsection{Heavy Metal Concentration in Plant Parts}

The highest Fe accumulation was observed in the roots of A.malaccensis in T5 (2770.75 ppm) (Fig. 2). 
Keeren Sundara Rajoo et al. / American Journal of Applied Sciences 10 (9): 952-964, 2013

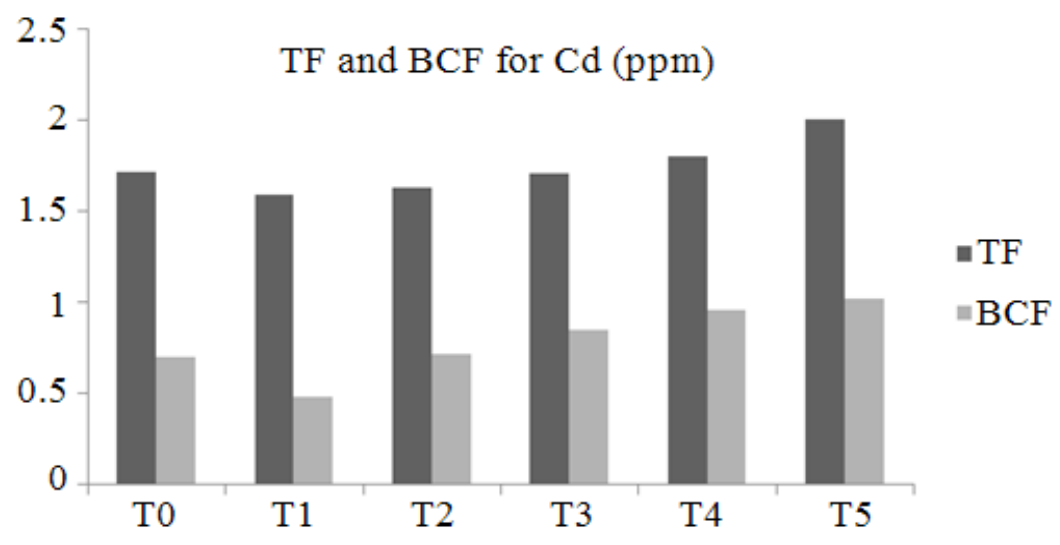

(a)

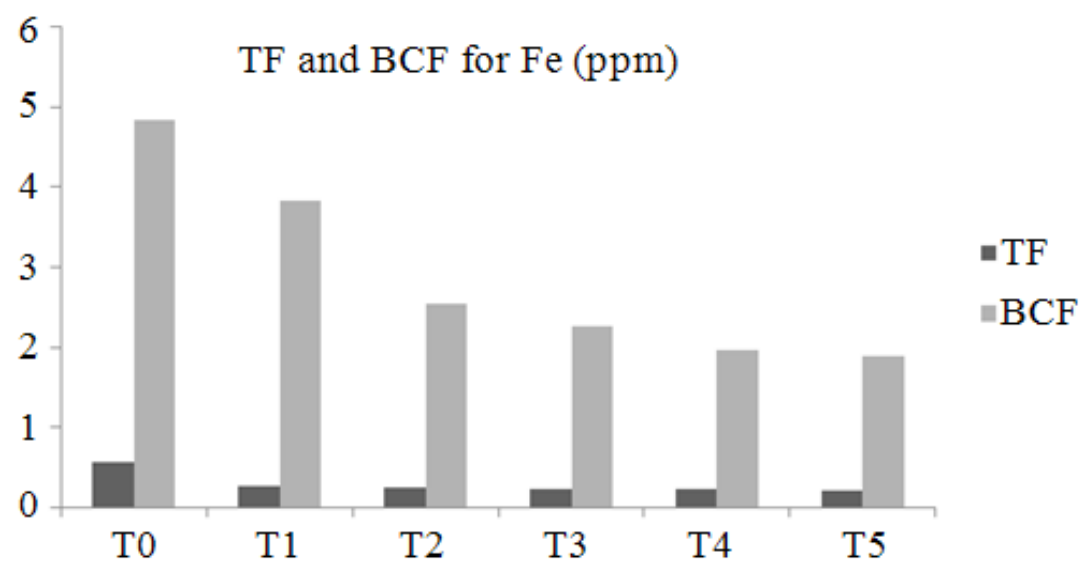

(b)

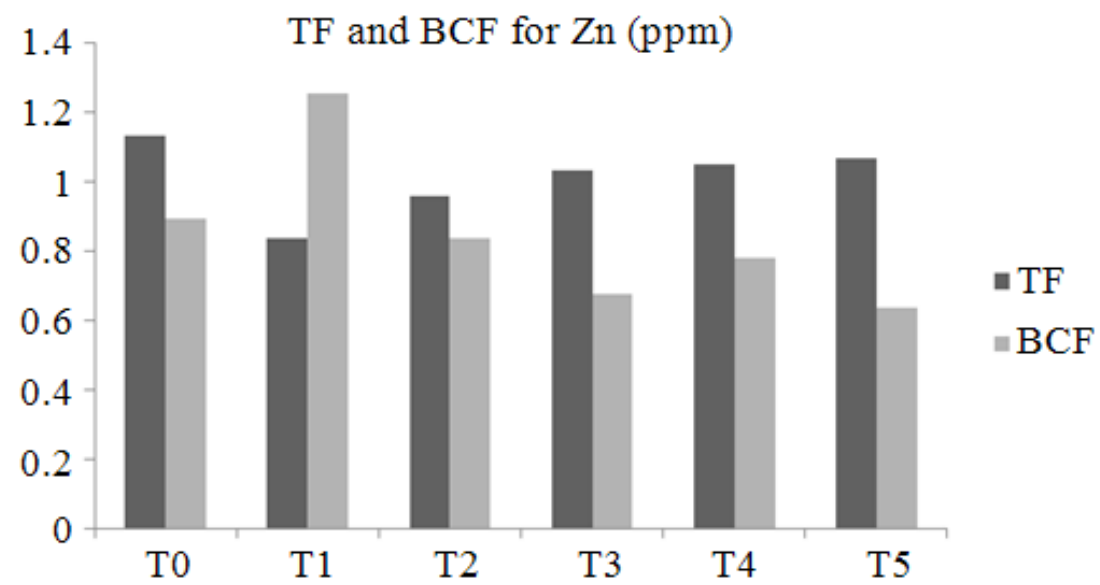

(c) 

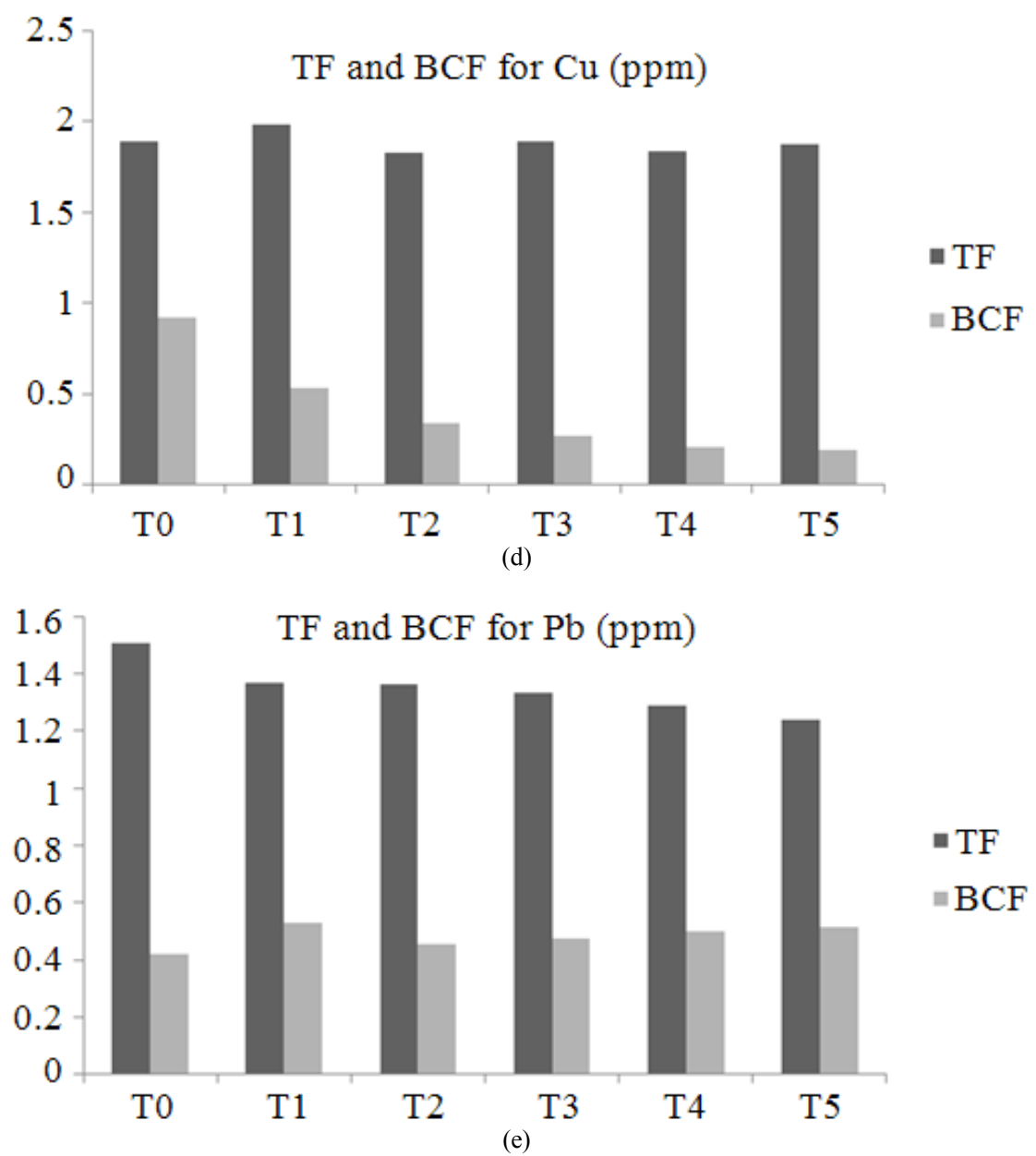

Fig. 3. Translocation factor and bioconcentration factor of $\mathrm{Cd}$ (a), $\mathrm{Fe}(\mathrm{b}), \mathrm{Zn}$ (c) $\mathrm{Cu}$ (d) and $\mathrm{Pb}$ (e) of A.malaccensis plant as influenced by different treatments. $\mathrm{T} 0=100 \%$ soil, $\mathrm{T} 1=80 \%$ soil $+20 \%$ sewage sludge, $\mathrm{T} 2=60 \%$ soil $+40 \%$ sewage sludge, $\mathrm{T} 3=40 \%$ soil $+60 \%$ sewage sludge, $\mathrm{T} 4=20 \%$ soil $+80 \%$ sewage sludge, $\mathrm{T} 5=100 \%$ sewage sludge

Furthermore, it was found that the leaves of the A.malaccensis absorbed higher levels of Fe compared to the stem. The stem of the A.malaccensis in T5 growth media accumulated the highest amount of $\mathrm{Cd}(3.75$ ppm), while the lowest concentration was observed in the leaves in T0 $(0.15 \mathrm{ppm})$. The highest $\mathrm{Zn}$ uptake was observed in the roots in the T5 growth media $(95.62$ $\mathrm{ppm}$ ), while the lowest $\mathrm{Zn}$ uptake was noted in the leaves at the $\mathrm{T} 0$ growth media $(8.74 \mathrm{ppm})$.

\subsection{Translocation Factor (TF) and Bioconcentration Factor (BCF) of Heavy Metals}

The TF for Fe was the lowest among all the other heavy metals. The lowest $\mathrm{TF}$ for Fe was recorded in
T5 (0.20) and the highest was recorded in T0 (0.55), as shown in Fig 3b. Besides that, Fe recorded the highest $\mathrm{BCF}$ among the heavy metals. The highest $\mathrm{BCF}$ for Fe was recorded in $\mathrm{T} 0$ (4.82), followed by $\mathrm{T} 1$ (3.82). For $\mathrm{Cu}$, the highest TF (1.98) was recorded in T1 (Fig. 3d), while the lowest $\mathrm{BCF}$ for $\mathrm{Cu}$ was recorded at $\mathrm{T} 5(0.18)$. The highest $\mathrm{TF}$ for $\mathrm{Pb}$ was recorded in T0 (1.51), while the lowest was in T5 (1.23) (Fig. 3e). The BCF for $\mathrm{Pb}$ was lowest in $\mathrm{T} 0$ and $\mathrm{T} 2$ treatments $(0.42$ and 0.45 , respectively). The TF for $\mathrm{Zn}$ was prominent in T3, T4 and T5 (1.03, 1.04 and 1.06 respectively), as shown in Fig 3c. The highest $\mathrm{BCF}$ for $\mathrm{Zn}$ was observed in $\mathrm{T} 1$ (1.25), while the lowest $\mathrm{BCF}$ for $\mathrm{Zn}$ was recorded at $\mathrm{T} 5$ treatment 
(0.64). Fig 3a showed that the highest TF for Cd was recorded in $\mathrm{T} 5(2.00)$, while the lowest $\mathrm{BCF}$ for $\mathrm{Cd}$ was recorded in $\mathrm{T} 1(0.48)$.

\section{DISCUSSION}

\subsection{Changes in Chemical Properties of Growth Media}

There was an increase in the $\mathrm{pH}$ of the growth media after harvest. The highest change in soil $\mathrm{pH}$ was recorded in $\mathrm{T} 3$ (5.13 to 5.32). The increase in $\mathrm{pH}$ was due to the uptake of acidic elements, such as $\mathrm{Fe}$ and other heavy metals, from the growth media by the A.malaccensis plant (Ghafoori et al., 2011). Furthermore, the application of sewage sludge in the growth media increased total carbon of each growth media. This indicates that sewage sludge has the ability to improve the overall organic matter content of the growth medium (Abdu et al., 2011), which in turn has the potential to improve the overall soil fertility (Rice, 2002). Therefore, sewage sludge has the potential to replace the usage of organic fertilizers, making it a viable, environment-friendly approach for the agriculture sector (Miranda, 2012). Besides that, soil organic matter improves the soil water holding capacity, making plants able to withstand short periods of droughts (Rice, 2002).

\subsection{Growth Performance and Plant Biomass}

The highest total height of the A.malaccensis plant $(47.55 \mathrm{~cm})$ was recorded in the T5. A.malaccensis plant in the T5 growth media also produced the highest number of leaves (20) and the highest basal diameter $(6.73 \mathrm{~cm})$. This shows that A.malaccensis exhibited the best growth in terms of height, number of leaves and basal diameter for the T5 growth media. Improvement in the growth parameters of A.malaccensis is due to the organic matter contribution by the sewage sludge (Majid et al., 2011; Parisa et al., 2010). Furthermore, these results indicate that the A.malaccensis plant has the ability to tolerate high levels of sewage sludge. T0 growth media exhibited the worst growth performance, indicating that a $100 \%$ soil growth media would be the least ideal growth media for the A.malaccensis plant, due to low organic matter content (Majid et al., 2011). After 16 weeks, T0 produced the lowest biomass of $63.65 \mathrm{~g}$ and $61.52 \mathrm{~g}$ for stem and leaves, respectively. T5 produced the highest biomass of $71.18 \mathrm{~g}, 70.00 \mathrm{~g}$ and $68.73 \mathrm{~g}$ for roots, stem and leaves, respectively. Plant biomass plays an important role in the absorption of heavy metals from soil and water, making A.malaccensis an ideal phytoremediator (Majid et al., 2011). Plant used as a phytoremediator must have both high potential capacity to absorb elements from soil or water and large biomass (Parisa et al., 2010). T5 also produced the highest biomass, indicating that this plant can be used for remediation of sludge contaminated soils (Majid et al., 2011). Hence, results in T5 proved that A.malaccensis is suitable as a phytoremediator of sludge contaminated soils.

\subsection{Heavy Metal Concentrations in Growth Medium}

There was a decrease in the heavy metal concentrations $(\mathrm{Cd}, \mathrm{Fe}, \mathrm{Zn}, \mathrm{Cu}$ and $\mathrm{Pb})$ in all growth media after planting and harvesting of the A.malaccensis plant. The highest decrease for all the heavy metal levels $(\mathrm{Cd}, \mathrm{Fe}, \mathrm{Zn}, \mathrm{Cu}$ and $\mathrm{Pb})$ in the A.malaccensis growth medium was observed in T5. High metal concentrations in the growth media of plants would normally restrict germination and negatively affect the roots, shoots and leaf growth of the plants (Parisa et al., 2010). In this study, however, the A.malaccensis plant did not exhibit any of these traits, indicating it's tolerance to high concentrations of heavy metals, making it a prospective phytoremediator species (Purakayastha and Chhonkar, 2010).

\subsection{Heavy Metal Concentration in Plant Parts}

The highest total concentration of heavy metal (Fe, $\mathrm{Zn}, \mathrm{Cu}, \mathrm{Cd}$ and $\mathrm{Pb}$ ) of the A.malaccensis plant was recorded in the T5 growth media. This is due to higher concentration of $\mathrm{Fe}, \mathrm{Zn}, \mathrm{Cu}, \mathrm{Cd}$ and $\mathrm{Pb}$ present in the $\mathrm{T} 5$ growth media; hence, higher uptake of the heavy metals by the A.malaccensis plant. Although an increase in the accumulation of heavy metals would typically affect the growth performance of a plant negatively (Abdu et al., 2011), the A.malaccensis plant did not exihibit any inhibition to its growth parameters. This is a clear indication that the A.malaccensis plant is highly tolerant to heavy metals, making it a suitable phytoextractor (Majid et al., 2011; Parisa et al., 2010). The highest accumulation of $\mathrm{Zn}$ (95.62 ppm) was recorded in the roots of A.malaccensis in the $\mathrm{T} 5$ growth medium. $\mathrm{Zn}$ accumulation is higher in the roots compared to the leaves and roots in all treatments. This indicates that A.malaccensis is able to tolerate $\mathrm{Zn}$ toxicity (Fontes and Cox, 1998). The stem of the A.malaccensis in T5 recorded the highest $\mathrm{Cd}$ accumulation (3.75 ppm), followed by the roots of the A.malaccensis in T5 $(2.55$ ppm). This is because $\mathrm{Cd}$ is a mobile heavy metal, 
easily transported from the root of the plant to the stem (Gregor et al., 2004). The roots of the A.malaccensis were found to absorb significantly higher levels of Fe compared to other plant parts. The highest root accumulation of Fe was recorded in T5 (2770.75 $\mathrm{ppm})$. The highest $\mathrm{Pb}$ in the roots was recorded in $\mathrm{T} 5$ (39.79 ppm), followed by T4 (37.29 ppm), while the lowest accumulation of $\mathrm{Pb}$ was noted in the leaves of $\mathrm{T} 0$ (16.08 ppm). The roots of the A.malaccensis in T5 had the highest uptake of $\mathrm{Cu}(8.51 \mathrm{ppm})$. The lowest $\mathrm{Cu}$ uptake was recorded in the stem of T0 $(5.31 \mathrm{ppm})$. The stem had lower levels of $\mathrm{Pb}$ and $\mathrm{Cu}$ compared to those in the roots due to their low mobility (Gregor et al., 2004).

\subsection{Comparison of Translocation Factor (TF) and Bioconcentration Factor (BCF) Among Treatments and Heavy Metals}

The TF for Fe was the lowest among all other TF (0.20 in T5), while it's BCF was highest among all other BCF (4.82 in T0). This is due to the A.malaccensis plant able to store a large percentage of its $\mathrm{Fe}$ uptake in its roots (Yoon et al., 2006). Low TF and high BCF is a clear indication that the A.malaccensis plant is not an ideal phytoextractor for $\mathrm{Fe}$, as ideal phytoremediator plants should store heavy metals in its stem. However, the TF for $\mathrm{Cu}$ was high (1.98 in T1), while its BCF was low $(0.18$ in $\mathrm{T} 5)$. This was also true for $\mathrm{Cd}$, where the $\mathrm{TF}$ for $\mathrm{Cd}$ was high (1.70 in T3), while its $\mathrm{BCF}$ was low (0.49 in T1). This indicates that the A.malaccensis plant could be a good phytoextractor of $\mathrm{Cu}$ and $\mathrm{Cd}$ (Majid et al., 2011; Parisa et al., 2010).

\section{CONCLUSION}

A.malaccensis plant was found to be able to tolerate heavy metals present in sewage sludge. The amount of heavy metal taken up by the A.malaccensis based on the translocation factor assessment was in the order:

$$
\mathrm{Fe}<\mathrm{Zn}<\mathrm{Pb}<\mathrm{Cu}<\mathrm{Cd}
$$

A.malaccensis is a potential phytoextractor of $\mathrm{Cd}$ and $\mathrm{Cu}$ as it can store these heavy metals in its stem as well as effectively remove $\mathrm{Zn}$ from the soils on which it is planted. High amount of $\mathrm{Fe}, \mathrm{Zn}$ and $\mathrm{Pb}$ was stored in the roots of the plant. Hence, A.malaccensis plant is not a suitable phytoremediator for $\mathrm{Fe}, \mathrm{Zn}$ and $\mathrm{Pb}$. The main use A.malaccensis is extraction of resin from its trunk. In practice, the trunk is harvested, but the roots containing $\mathrm{Fe}, \mathrm{Zn}$ and $\mathrm{Pb}$ would remain in the soils.

\section{ACKNOWLEDGEMENT}

We wish to acknowledge the technical and the financial support given by Universiti Putra Malaysia (UPM) and the Ministry of Higher Education, Malaysia (MOHE) through Fundamental Research Grant Scheme (FRGS).

\section{REFERENCES}

Abdu, A., N. Aderis, A. Abdul-Hamid, N.M. Majid and S. Jusop et al., 2011. Using orthosiphon stamineus $B$. for phytoremediation of heavy metals in soils amended with sewage sludge. Am. J. Applied Sci., 8: 323-331.

Bennett, L.E., J.L. Burkhead, K.L. Hale, N. Terry and M. Pilon et al., 2003. Analysis of transgenic Indian mustard plants for phytoremediation of metalcontaminated mine tailings. J. Environ. Q., 32: 432440. PMID: 12708665

Fontes, R.L.F. and F.R. Cox, 1998. Zinc toxicity in soybean grown at high iron concentration in nutrient solution. J. Plant Nutr., 21: 1723-1730. DOI: 10.1080/01904169809365517

Ghafoori, M., N.M. Majid, M.M. Islam and S. Luhat, 2011. Bioaccumulation of heavy metals by Dyera costulata cultivated in sewage sludge contaminated soil. Afr. J. Biotechnol., 10: 10674-10682.

Gregor, W., M.F. Mette, Staginnus, C., Matzke, M. A. and A.J.M. Matzke, 2004. A distinct endogenous pararetrovirus family in Nicotiana tomentosiformis, a diploid progenitor of polyploid tobacco. Plant Physiol., 134: 1191-9. PMID: 14988473

IWK, 1997. Sewage treatment plant. Indah Water Konsortium.

Jackson, M.L., 1973. Soil Chemical Analysis. 1st Edn., Prentice Hall of India Pvt. Ltd., New Delhi, pp: 498.

Jos, A.C.V., G.G. Avi, M.A. Danuta, P.S. Jean and S. Peter, 2009. Dualities in plant tolerance to pollutants and their uptake and translocation to the upper plant parts. Environ. Exp. Botany, 67: 10-22. DOI: 10.1016/j.envexpbot.2009.05.009

Karen, E.G., D.H. Xiao, R.G. Bernard and M.G. Bruce, 2009. Phytoremediation and rhizoremediation of organic soil contaminants: Potential and challenges. Plant Sci., 176: 20-30. DOI: 10.1016/j.plantsci.2008.09.014

Kvesitadze, G., G. Khatisashvili, T. Sadunishvili and J.J. Ramsden, 2006. Biochemical Mechanisms Of Detoxification in Higher Plants: Basis of Phytoremediation. 1st Edn., Springer, New York, ISBN-10: 3540289968, pp: 262. 
Majid, N.M., M.M. Islam, V. Justin, A. Abdu and P. Ahmadpour, 2011. Evaluation of heavy metal uptake and translocation by Acacia mangium as a phytoremediator of copper contaminated soil. Afr. J. Biotechnol., 10: 8373-8379.

Miranda, A.S., 2012. Breaking the impasse in the international climate negotiations: The potential of green technologies. Energy Policy, 48: 5-12. DOI: 10.1016/j.enpol.2012.04.044

Nicholas, L. and S. Daniel, 2008. America's bottom-up climate change mitigation policy. Energy Policy, 36: 673-685.

Olivier, B., 2006. Global warming: Should companies adopt a proactive strategy? Long Range Plann., 39: 315-330. DOI: 10.1016/j.lrp.2006.07.002

Parisa, A., M.N. Azmi, A. Abdu, A.H. Hazandy and K.S. Daljit et al., 2010. Uptake of heavy metals by Jatropha curcas L. Planted in soils containing sewage sludge. Am. J. Applied Sci., 7: 1291-1299.

Purakayastha, T.J. and P.K. Chhonkar, 2010. Phytoremediation of Heavy Metal Contaminatrd Soils. In: Soil Heavy Metal, Sherameti, A.V.I. (Ed.), Springer, Heidelberg, pp: 397-398.

Rascio, N. and F. Navari-Izzo, 2011. Heavy metal hyperaccumulating plants: How and why do they do it? And what makes them so interesting. Plant Sci., 180: 169-181. DOI: 10.1016/j.plantsci.2010.08.016

Raymond, A.W. and E.O. Felix, 2011. Heavy Metals in Contaminated Soils: A review of sources, chemistry, risks and best available strategies for remediation. ISRN Ecol., 2011: 402647-402647. DOI: $10.5402 / 2011 / 402647$
Reeves, R.D. and A.J.M. Baker, 2000. Metal Accumulating Plants. In: Phytoremediation of Toxic Metals: Using Plants to Clean Up the Environment, Raskin, I. and B.D. Ensley (Eds.), Wiley, New York, ISBN-10: 0471192546, pp: 193-229.

Rice, C.W., 2002. Storing carbon in soil: Why and how? Geo Times.

Sahoo, S.K., Y. Muramatsu, S. Yoshida, H. Matsuzaki and W. Ruhm, 2009. Determination of (129)I and (127)I concentration in soil samples from the Chernobyl $30-\mathrm{km}$ zone by AMS and ICP-MS. J. Radi. Res., 50: 325-332. PMID: 19542689

Singh, R.P. and M. Argawal, 2008. Potential benefits and risks of land application of sewage sludge. Waste Manage., 28: 347-358. DOI: 10.1016/j.wasman.2006.12.010

Soehartono, T. and A. Newton, 2000. Conservation and sustainable use of tropical trees in the genus Aquilaria I. Status and distribution in Indonesia. Biol. Conservation, 96: 83-94. DOI: 10.1016/S00063207(00)00055-0

Yoon, J., X.D. Cao, Q.X. Zhou and L.Q. Ma, 2006. Accumulation of $\mathrm{Pb}, \mathrm{Cu}$ and $\mathrm{Zn}$ in native plants growing on a contaminated Florida site. Sci. Total Environ., 368: 456-464. DOI: 10.1016/j.scitotenv.2006.01.016 